Acta vet. scand. 1990, 31, 381-383.

Brief Communication

\title{
Biochemical Characterization of Trichinella in Greenland
}

In 1961 Madsen published detailed studies on the prevalence rates of Trichinella infections in sledge dogs and wild mammals in Greenland. The highest frequency was registrated among sledge dogs with a prevalence rate of $61.9 \%$ while the corresponding rate among polar bears was $24.2 \%$. Studies on polar bears carried out during the 80 'es have demonstrated a prevalence rate comparable to that reported by Madsen (1961) (Born \& Henriksen, in preparation). In Greenland infections with Trichinella have also been observed in walruses (Madsen 1961, Thing et al. 1976, Born et al. 1982), in seals and arctic foxes (Madsen 1961), and in man (Thorborg et al. 1948, Bohm, cit. James 1989).

Considering the high genetic variability of the Trichinella genus (Dick 1983) studies on the identification of isolates of Trichinella from Greenland by enzyme system analyses have been carried out. Previous studies on Trichinella isolates originating from other regions of the world have demonstrated the presence of seven distinct gene pools designated T1 to T7 (Pozio et al. 1989a, La Rosa et al. 1989). All arctic isolates examined so far have been referring to the same gene pool (T2) assumed as T. nativa, characterized by e.g. resistance to freezing $\left(-20^{\circ} \mathrm{C}\right)$ and a low infectivity to laboratory rats (Rausch 1970).

In the present investigation two Trichinella isolates from Greenland were studied, one obtained from a sledge dog (DOG, code MCAN/DK/81/ISS83) in the Qaanaaq district (Thule area) (Lat $77^{\circ} \mathrm{N}$, Long $69^{\circ} \mathrm{W}$ ) and the other from a polar bear (BEAR, code MURS/DK/82/ISS84) shot in the Na- nortalik district (Lat $60^{\circ} \mathrm{N}$, Long $45^{\circ} \mathrm{W}$ ). The isolates have been maintained through 5 (DOG) and 4 (BEAR) passages in guinea pigs and subsequently through 11 (DOG) and 10 (BEAR) passages in Swiss mice prior to biochemical identification.

Twenty-seven enzyme systems were examined in using $12 \%$ horizontal starch gel electrophoresis: a PGD (1.1.1.8), LDH (1.1.1.27), MDH (1.1.1.37), $\mathrm{ME}$ (1.1.1.40), IDH (1.1. 1.42), 6PDG (1.1.1.44), G6PD (1.1.1.49), G3DP (1.2.1.12), GLDH (1.4.1.3), SOD (1.15.1.1), GOT (2.6.1.1), ALAT (2.6.1.2), AK (2.7.4.3), PGM (2.7.5.1), ES (3.1.1.1), ACPH (3.1.3.2), PEP1 (3.4.1.1), PEP2 (3.4.1.1), ADA (3.5.4.4), ALDO (4.1.2.13), CA (4.2.1.1), FUM (4.2.1.2), ACON (4.2.1.3), ENOL (4.2.1.11), TPI (5.3.1.1), MPI (5.3.1.8) and GPI (5.3.1.9).

The Greenland isolates were compared with the reference strains used by the Trichinella Reference Centre (Pozio et al. 1989b). The 2 isolates presented similar allozymic patterns with only GLDH enzyme different from one another: BEAR isolate showed one low band whereas DOG isolate showed 3 bands (Fig. 1). The average genetic similarity of. Greenland parasites with respect to the reference strains was calculated according to Jaccard's similarity index $(\mathrm{J}): \mathrm{J}=27 \%$ vs. $\mathrm{T} 1$ ( $T$. spiralis), $\mathrm{J}=98 \%$ vs. T2 ( $T$. nativa), $\mathrm{J}=55 \%$ vs. T3 (Trichinella type 3, present in Europe and Asia), $\mathrm{J}=20 \%$ vs. T4 (T. pseudospiralis) and $\mathrm{J}=44 \%$ vs. T7 ( $T$. nelsoni). These results support the idea that gene flow is very low or absent among Trichinella gene pools. The factorial analyses of correspond- 


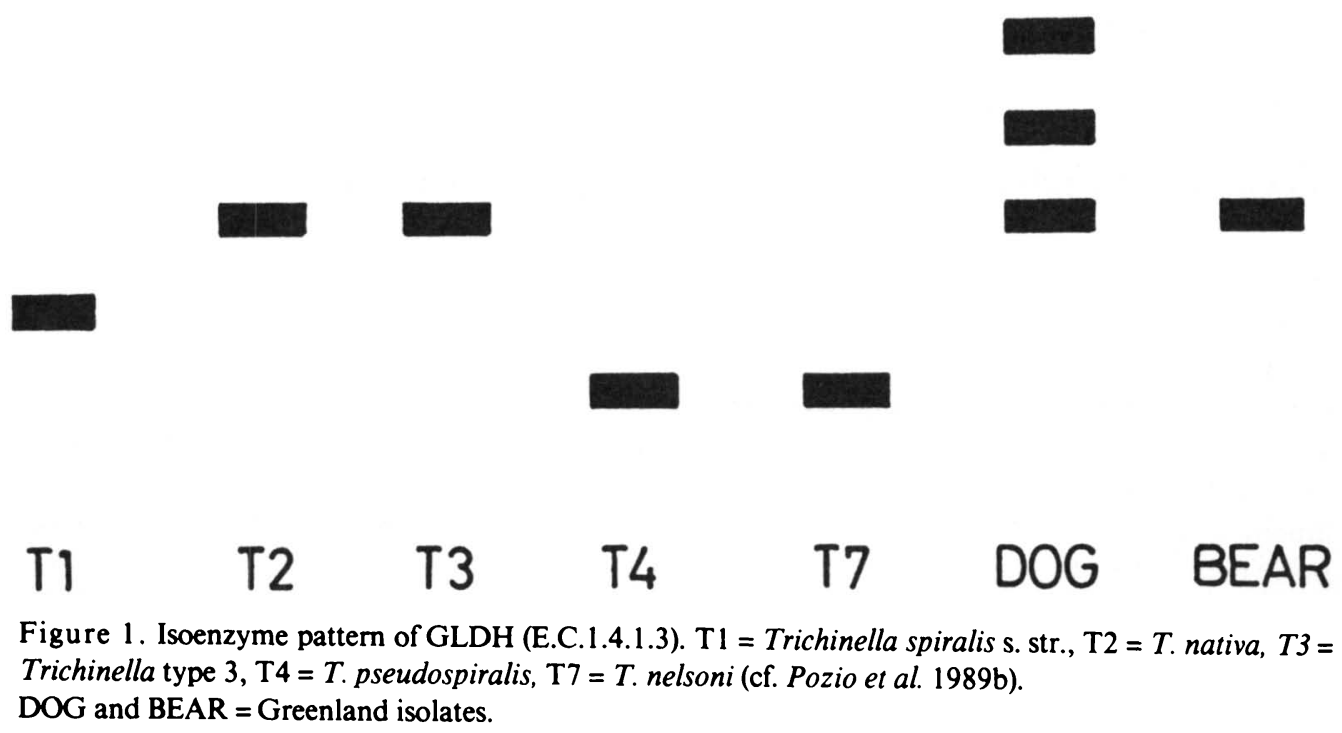

ences (La Rosa et al. 1989) demonstrate that the Greenland genotypes were located within the range of the variation of the $T$. nativa gene pool.

A GLDH pattern comparable to the one observed in the DOG isolate has previously been observed in four $T$. nativa isolates originating from the Svalbard Islands, Norway, and from the Primorsk region, USSR. The results seem to indicate a gene flow among $T$. nativa isolates from places far apart, respectively that the GLDH variant pattern could be utilized as a genetic marker for the parasite and for host dispersion. Thus the biochemical analyses of a higher number of isolates, obtained from different places in Greenland, may explain the correlations between parasite (genetic variants), host, and distribution.

The presence of geographic boundaries is not to be expected as to a parasite like Trichinella which infects homeothermic animals. Therefore the arctic fauna has a potential contact through the icefield in the Polar Sea, and subsequently the ice could help to spread out Trichinella gene variants in the arctic and subarctic areas. Finally it seems relevant to consider that factors related to climatic and host conditions may regulate the distribution and the evolution of Trichinella species, in particular considering $T$. nativa, which primarily seems confined to the arctic and subarctic regions of the world.

\section{Acknowledgements}

The authors wish to thank Jeppe Bohm and Lars Klenow, who supplied us with muscles from the dog and the polar bear, respectively.

\section{G. La Rosa and E. Pozio,}

Laboratory of Parasitology, Istituto Superiore di Sanita, Rome, Italy.

\section{Sv. Aa. Henriksen,}

National Veterinary Laboratory, Copenhagen, Denmark.

\section{References}

Born EW, Clausen B, Henriksen SvAa: Trichinella spiralis in walruses from the Thule district, North Greenland, and possible routes of 
transmission. Z. f. Säugetierkunde 1982, 47 , 246-251.

Born EW, Henriksen SVAa: Prevalence of Trichinella $s p$. in polar bears (Ursus maritimus) from northeastern Greenland. (In preparation).

Dick TA: Species, and Intraspecific Variation. In: "Trichinella and Trichinosis", Ed. W. C. Campbell, Plenum Press, New York and London 1983, pp. 31-73.

James ER: Trichinella Olympics. Parasitol. Today, 1989, 5, 66-67.

La Rosa G, Pozio E, Rossi P: New taxonomic contribution to the genus Trichinella Railliet, 1989. II. Multivariate analyses on genetic and biological data. In: ICT 7th Trichinellosis. Ed. C. E. Tanner. S.S.I.S. Press, Madrid 1989, pp. 103-108.

Madsen $H$ : The distribution of Trichinella spiralis in sledge dogs and wild mammals in Greenland - under a global aspect. Meddelelser om
Grønland, 159, No. 7, C. A. Reitzels Forlag, Copenhagen 1961.

Pozio E, La Rosa G, Rossi P, Murrell KD: New taxonomic contribution to the genus Trichinella Railliet, 1989. I. Biochemical identification of seven clusters by gene-enzyme systems. In: ICT 7th Trichinellosis. Ed. C. E. Tanner, S.S.I.S. Press, Madrid 1989a, pp. 76-82.

Pozio E, La Rosa G, Rossi P: Trichinella Reference Centre. Parasitol. Today, 1989b, 5, 169170.

Rausch RL: Trichinosis in the Arctic. In: "Trichinosis in Man and Animals". Ed. S. E. Gould. Charles C. Thomas, Springfield, Illinois 1970, pp. 348-373.

Thing $\mathrm{H}$, Clausen B, Henriksen SvAa: Finding of Trichinella spiralis in a walrus (Obodenus rosmarus $L$.) in the Thule District, Northwest Greenland. Nord. Vet.-Med. 1976, 28, 59.

Thorborg NB, Tulinius S, Roth H: Trichinosis in Greenland. Acta Pathol. 1948, 25, 778-794.

(Received April 27, 1990; accepted June 12, 1990).

Reprints may be requested from: E. Pozio, Laboratory of Parasitology, Istituto Superiore di Sanita, Viale Regina Elena, 299, I-00161 Rome, Italy. 